\title{
Econometric Algorithms Applied to the Incidence of Income on Satisfaction with Quality of Life in Latin American Capitals
}

\author{
Carolina Henao-Rodríguez ${ }^{1}$, Mercedes Gaitán-Angulo ${ }^{2,4}$, \\ Jenny Paola Lis-Gutiérrez ${ }^{3,4(\bowtie)}$, and Leonor Mojica Sánchez ${ }^{5}$ \\ 1 Unipanamericana Fundación Universitaria, Bogotá, Colombia \\ 1chenaor@unipanamericana.edu.co \\ 2 Corporación Universitaria Empresarial de Salamanca, Barranquilla, Colombia \\ m_gaitan689@cues.edu.co \\ 3 Universidad de la Costa, Barranquilla, Colombia \\ jlis@cuc.edu.co \\ 4 Universidad de Granada, Melilla, Spain \\ \{e.mercedesgaitan, e.jennypaolalis\}@go.ugr.es \\ 5 Corporación Universitaria del Meta, Villavicencio, Colombia \\ leonor.mojica@unimeta.edu.co
}

\begin{abstract}
The purpose of this research is to determine the incidence of income on the satisfaction of quality of life in Latin American capitals. The data was taken from the CAF Survey in 2017 (ECAF), made by Development Bank of Latin America. To do this, an econometric model was constructed which represents the relationship between the studied variables. Among the main findings, it was identified that, except for Mexico City, in all the analyzed cities a deteriorated state of health reduces the probability that the individual feels satisfied with his or her life. Therefore, health is a crucial element to increase the citizens' perception of the quality of life in Latin American cities.
\end{abstract}

Keywords: Income $\cdot$ Life satisfaction · Quality of life · Econometric studies · Latin America

\section{Introduction}

In countries, the economic development and quality of life level are not only related to income, since in addition to per capita income other factors largely affect the socioeconomic development in a country [1]. Quality of life is an indicator that, in addition to being dependent on many factors, presents the essential features that make this a complex indicator. In a first instance, apparently, the economic development of a country would guarantee a growing trend in the standard of living of its citizens. In practice, the observed facts do not confirm this hypothesis: a substantial number of countries above the average in economic growth present state regulations that do not fully guarantee 
human rights, in addition to production systems that are highly harmful to the natural environment. [2].

In Latin American countries there are problems associated with inequality and economic growth that is concentrated in a few sectors and territories [3], which impedes a better quality of life for its inhabitants. It is therefore of great importance that Latin American countries develop effective public policies that improve the living conditions of their inhabitants so that their welfare receives a significant positive impact. For an adequate understanding, inequality should be studied from its structure to facilitate a holistic approach that allows observing it from different perspectives: the spatial concentration of resources, assets and opportunities and differences in quality of life and well-being among the different territories [4].

From the above reflection, it is essential to achieve a comparative analysis of the influence of income on satisfaction and quality of life in Latin America, considering the particularities of the environment, and relying on econometric techniques that allow establishing causal relationships in a quantitative way.

\section{State of the Art}

The role of the state in improving the quality of life and economic growth is a hot topic at present. [5] stated that, at present, a fundamental task is the definition of the role that the government of a country should play in its economic development. When, in a country it is found that the information is not correct, adequate or sufficient, as well as there are imperfect markets, it is possible that its legislation and government systems have tools that allow them to promote better standards of living. [6].

Complexity greatly limits the study of indicators of quality of life and well-being, as shown by the few interdisciplinary studies that have been published about the use of indicators. In addition, the indicators of quality of life, well-being and sustainability have weak theoretical support, future research must be centered on find key indicators, which are fundamental when trying to interpretate and contextualize the complex dynamics under study [7]. Among the most recent studies about quality of life we can find the work of [8] who studied the Organization for Economic Cooperation and Development countries and found that developed countries have as a characteristic attribute a decelerated economic growth, since the growth rate of their GDP has increased between 2 and 3 times in the last 50 years. In agreement with the Easterlin paradox, long term dynamics of the GPD in developed countries show that richer persons don't present a higher life quality satisfaction. Furthermore, studies on that dynamics found and statistically irrelevant correlation between the rate of change in GPD and life satisfaction.

[9] used the self-reported happiness of American citizens between 1976 and 2006 found strong evidence to affirm that the perception of happiness increased when the state government made more investment in the supply of public goods. [10] studied the dispersion and growth of immigrant in the United States for 366 metropolitan in 2010. They examined how immigration has influenced four dimensions of quality of life: economic well-being, social welfare, healthy living and urban mobility. The authors found that the concentration of immigrants tends to have negative effects on the quality of urban life, but these effects dissipate when considering the diversity of immigrants. 
[11] examined the different levels of health and social security services in rural and urban areas of China and India, with representative data at the national level of individuals 50 years of age or older, between 2008 and 2010 in China and 2007 and 2008 in India.

\section{Methodology}

\subsection{Data}

The data was taken from the CAF Survey in 2017 [12], made by the Development Bank of Latin America, taking as a sample individuals in households and conducted annually since 2008 in the main cities of Latin America. The survey collects demographic and socioeconomic information from the individuals in the sample, and records information about a set of characteristics at the household level. The survey contains general modules that allow estimates on access, quality, spending and satisfaction in urban transport services, security, garbage collection, water and sanitation, electricity and housing. The universe under study was the urban population between 20 and 60 years old, residents in the cities included in the sample, these were Buenos Aires, Bogota, La Paz, Lima, Mexico City, Montevideo, Panama City, Quito, São Paulo and Santiago.

To guarantee a balanced sample that would allow the study population to be represented, sex and age quotas were used, and 12 demographic groups were used, so that the distribution of the sample between groups did not differ statistically from the population distribution in each city. The data from the ECAF were collected using a stratified, multistage cluster sampling design. In addition, the 2017 ECAF includes multiple imputations to alleviate the problem of lost/un-reported information on personal income.

\subsection{Variables}

The endogenous variable is the answer to the question (P3): how satisfied are you with your life? On a scale of 1 to 10,1 is "Not satisfied" and 10 is "Totally satisfied".

The exogenous variables are (i) level of income, (ii) subsidies received from the government, (iii) marital status, (iv) health and (v) education. Next, each of these variables is explained.

Logingre: logarithm of the monthly income level. Because the income variable was imputed, the logarithmic transformation was performed on all its versions. The most efficient way is using the command.

P48_1: If in the last three months the individual received subsidies, social plans or social assistance from the government

P4: Marital status (single (2), separated (3), widow (4) and living/united freely (5)) P41: Appreciation by the individual about his health (very good (2), good (3), regular (4), bad (5))

P49: Employment status: (owner or partner of a business of its own (2), employed in a private sector company or institution (3), employed in a public sector institution or company (4), worker of a cooperative (5); worker of domestic service in private households (6), unpaid family worker (7).) 
P101_1: Level of education (without instruction (1), preschool (2), basic/incomplete primary (3), basic/complete primary (4), secondary/diversified media and professional/incomplete high school (5), secondary/diversified media and professional/complete high school (6), incomplete university/tertiary non-university (7), full university/tertiary non-university (8), incomplete university (9), full university (10), specialization/master/doctorate (11).

\subsection{Model}

The dependent variable that is the answer to: on a scale of 1 to 10 where 1 is "Not at all satisfied" and 10 is "Totally satisfied", how satisfied are you with the life you lead? which is a discrete ordinal variable. In the ordinal family, the answer Y assumes one of the $\mathrm{k}$ single values. Actual values are irrelevant, except that it is assumed that the highest values correspond to "higher" results. Without loss of generality, it is assumed that Y assumes the values $1 ; \ldots ; \mathrm{k}$. The ordinal family with $\mathrm{k}$ results has cutoff points $\mathrm{k}_{0} ; \mathrm{k}_{1} ; \ldots$, $\mathrm{k}_{\mathrm{k}}$, where $\mathrm{k}_{0}=-\infty, \mathrm{k}_{\mathrm{y}}<\mathrm{k}_{\mathrm{y}+1} \mathrm{yk}_{\mathrm{k}}=\infty$. The coefficients were estimated using the maximum likelihood as described in this parameterization. No constant appears, because the effect is absorbed at the cut points. The probability of a given observation for ordered logit is:

$$
\begin{aligned}
& P_{i j}=\operatorname{Pr}\left(y_{j}=i\right)=\operatorname{Pr}=\left(\kappa_{i}-1<x_{j} \beta+u \leq \kappa_{i}\right) \\
& =\left(1 /\left(1+\exp \left(-\kappa_{i}+x_{j} \beta\right)\right)-\left(1 /\left(1+\exp \left(-\kappa_{i-1}+x_{j} \beta\right)\right.\right.\right.
\end{aligned}
$$

The imputed values were obtained from the models chain

$$
\begin{gathered}
\mathrm{Y} 1^{(\mathrm{t}+1)} \sim \mathrm{g}\left(\mathrm{Y}_{1} \mid \mathrm{Y}_{2}^{(\mathrm{t})}, \ldots, \mathrm{Yk}^{(\mathrm{t})}, \mathrm{Z} ; \varphi 1\right) \\
\mathrm{Y} 2^{(\mathrm{t}+1)} \sim \mathrm{g}\left(\mathrm{Y}_{2} \mid \mathrm{Y}_{1}^{(\mathrm{t}+1)}, \mathrm{Y} 3^{(\mathrm{t})}, \ldots, \mathrm{Yk}^{(\mathrm{t})}, \mathrm{Z} ; \varphi 2\right) \\
\mathrm{Yk}^{(\mathrm{t}+1)} \sim \mathrm{g}\left(\mathrm{Yk} \mid \mathrm{Y} 1^{(\mathrm{t}+1)}, \mathrm{Y} 2^{(\mathrm{t}+1)}, \ldots, \mathrm{Y}_{\mathrm{k}-1}^{(\mathrm{t}+1)}, \mathrm{Z} ; \varphi k\right)
\end{gathered}
$$

By iterating $\mathrm{t}=0,1, \ldots, \mathrm{T}$ times until obtain convergence at $\mathrm{t}=\mathrm{T} ; \varphi \mathrm{j}, \mathrm{j}=1, \ldots, \mathrm{k}$ represents the model parámeter $g$ for the variable $\mathrm{Yj}$ [13].

\section{Results}

An estimate was made for each country except Venezuela due to the highly irregular alterations on its official exchange rate which produce skewness in the estimate. Each output is the result of adding 11 ordinal regressions, equivalent to analyzing 11 databases, the original and the 10 bases formed by each imputation and the variables derived from them, and then add these regressions, as shown below. The F test showed in all the models that it can not be rejected that the models are statistically significant, with a level of significance of $1 \%$. The auxiliary parameters are not specified in this document, since they are the cut-off points, as shown below (Table 1). 
Table 1. Variables statistically significant

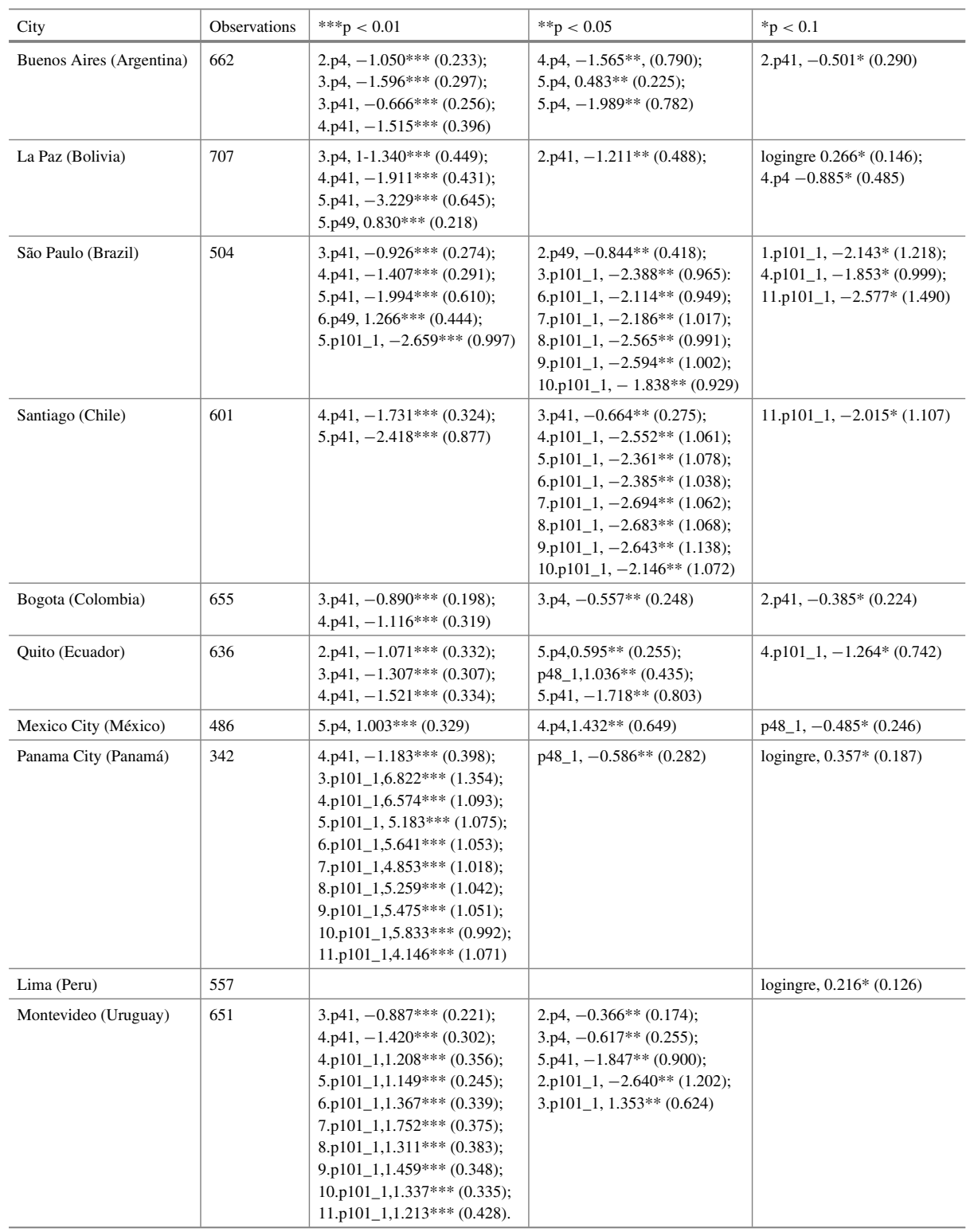

The empirical evidence showed that La Paz, Lima and Panama City are the only cities that presented a growing and significant association between the satisfaction that the individual reported with his life and income, therefore, for these countries the probability of an increase in The perception of satisfaction with their quality of life increases with income. 
The coefficient corresponding to logingre shows a value with a higher value in the case of Panama City. We proceeded to test if the estimated difference is significant. For this purpose, the conversion of the currency of Bolivia and Peru to USD was made at the time of collection according to the official exchange rates. An estimate was made where the only exogenous variable was the logarithm of the income in dollars. To compare these countries, we then proceeded to estimate the difference between the parameters using the standard errors and data from the estimation of the previous model.

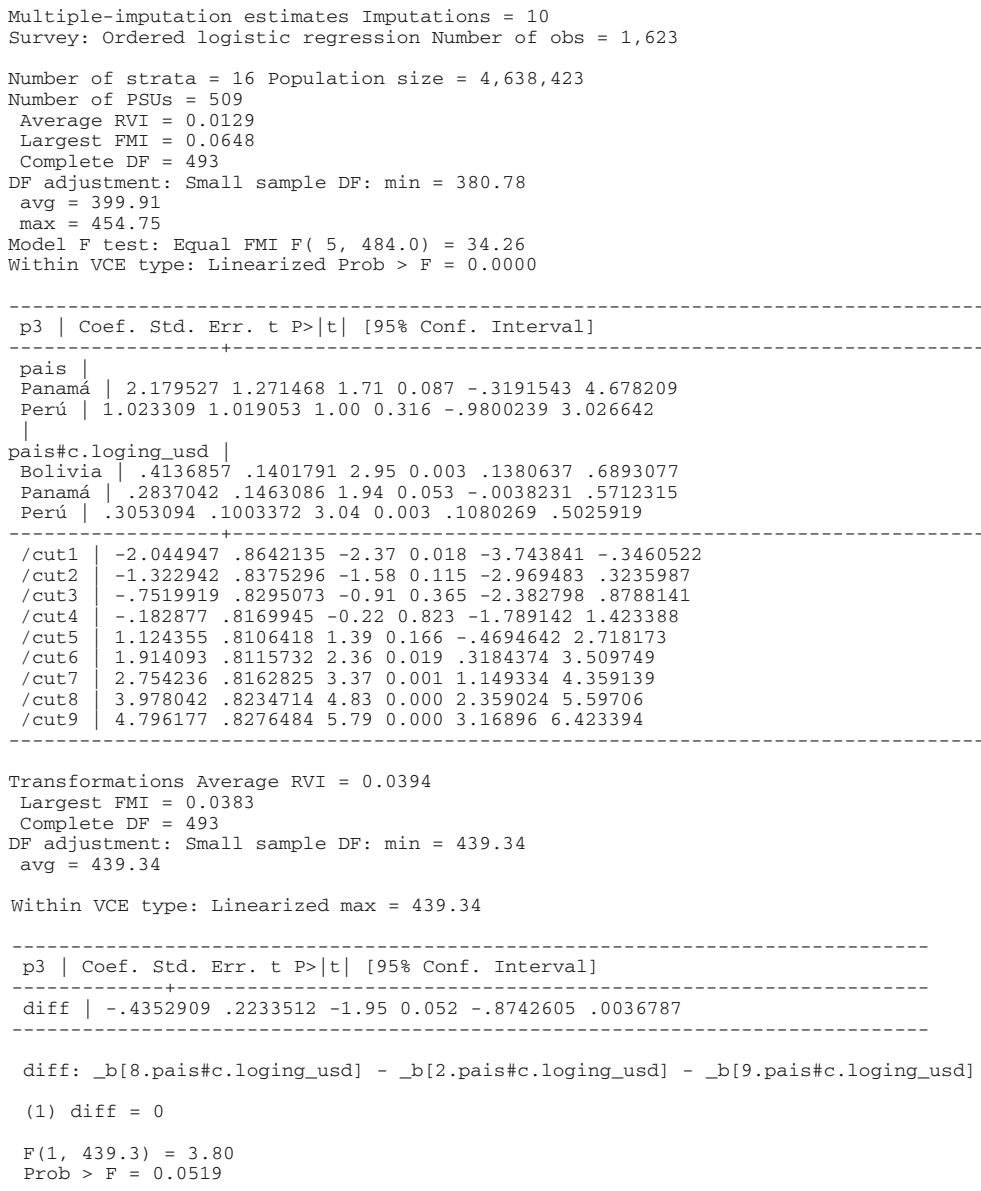

The joint tests of transformed coefficients (the differences) showed that the difference observed is not statistically significant at a level of significance of $5 \%$.

\section{Discussion}

The empirical evidence showed that for all the cities analyzed, except for Mexico City, a more deteriorated state of health reduces the probability that the individual feels satisfied with his or her life. Therefore, health is a crucial element to increase the quality of life of 
citizens. In this context, economic development is often not a linear process of economic growth, so social security is a mechanism that is necessary in a market economy to rise the quality of life of the habitants. In this context, the government must create and maintain a social security net, including access to basic health services, since living standards cover more than the variables captured in GDP statistics [11].

In Buenos Aires, marital status is a significant variable, where "separate" is the marital status that decreases the likelihood that the individual feels satisfied with their life and "lives with a partner" is the marital status that decreases less the probability of increasing the perception of the quality of life. The education, the profession, the level of income and the subsidies received by the citizens in the last three months were not significant.

The results obtained showed that in La Paz there is a positive and significant relationship between the probability that an individual feels satisfied with his life and the level of income. Widowhood is the marital status that decreases the likelihood of satisfaction with the quality of life. The workers of a cooperative are more likely to increase the perception of satisfaction with their life. The educational level and subsidies, social plans or government social assistance received in the last three months were not significant in the estimation.

In São Paulo, the estimations showed that single people are more likely to feel satisfied with their lives. Working in domestic service presented a positive relationship with the probability of satisfaction with the life that leads, this may be due to the fact that in other professions higher levels of stress can be managed. However, this issue should be addressed by new studies that empirically validate the previous statement. Education on the other hand, presented a significant and negative relationship with the satisfaction that individuals reported with their lives. The level of income and subsidies received by citizens in the last three months were not significant.

The data studied for Santiago de Chile showed that divorced people are less likely to feel satisfied with their lives. Education presented a significant and negative relationship with the satisfaction that individuals reported with their lives, as was observed for the estimates made for São Paulo. The level of income, the employment situation and the subsidies received by the citizens in the last three months were not significant in the proposed models.

The empirical evidence for Bogotá showed that, as evidenced in Santiago de Chile, divorced persons are less likely to feel satisfied with their lives. The level of income, the employment situation and the subsidies received by the citizens in the last three months were not significant.

For Quito it was possible to conclude that the subsidies received by the citizens in the last three months increase the probability of satisfaction with the quality of life. People who have a complete primary school level are less likely to have greater life satisfaction [14]. Finally, the income level and the employment situation were not significant in the estimates.

In contrast to what was evidenced in Quito, in Mexico City it was evident that the subsidies received by the citizens in the last three months decrease the probability of satisfaction with the quality of life increase. Widowed people who live with a partner 
are more likely to increase their satisfaction with their lives. Variables such as income level, health, education and employment situation were not significant.

The estimate made for Panama City showed that there is a positive and significant relationship between the probability that an individual feels satisfied with their life and the level of income. Subsidies, social plans or government social assistance received in the last three months reduce the probability of satisfaction with the quality of life. Marital status and profession were not significant. Finally, the educational level presents a positive and significant relationship with the probability of feeling satisfied with their life, as compared to what was found in Santiago de Chile and São Paulo.

In Lima there is a positive and significant relationship between the level of income and the probability that an individual feels satisfied with their life, as well as the performance of unpaid family work. Divorce is the marital status that decreases the likelihood of satisfaction with the quality of life. The educational level and subsidies, social plans or government social assistance received in the last three months were not significant.

The study conducted for Montevideo showed that single and separate are the civil states that are significant and diminish the probability that the individual feels satisfied with their life. The income level, job performance and subsidies, social plans or government social assistance received in the last three months were not significant. Finally, the educational level have a positive and significant relationship with the likelihood of feeling satisfied with their lives, except for people who have pre-school studies that have a negative relationship with the probability that the individual reports greater satisfaction with their current life.

\section{References}

1. Chisadza, C., Bittencourt, M.: Economic development and democracy: the modernization hypothesis in sub-Saharan Africa. Soc. Sci. J. 56(2), 243-254 (2019). https://www.sciencedi rect.com/science/article/pii/S0362331918301484

2. Hajduová, Z., Andrejovský, P., Beslerová, S.: Development of quality of life economic indicators with regard to the environment. Procedia - Soc. Behav. Sci. 110(24), 747-754 (2014). https://www.sciencedirect.com/science/article/pii/S1877042813055596

3. Economic Commission for Latin America and the Caribbean: La ineficiencia de la desigualdad (LC/SES.37/3-P): Santiago de Chile: CEPAL (2018). https://www.cepal.org/es/publicaci ones/43442-la-ineficiencia-la-desigualdad

4. Economic Commission for Latin America and the Caribbean: Desarrollo territorial en América Latina y el Caribe: desafíos para la implementación de la agenda 2030 para el desarrollo sostenible (LC/MDCRP.27/3). Santiago de Chile: CEPAL (2018). https://www.cepal.org/es/publicaciones/43972-desarrollo-territorial-america-latinacaribe-desafios-la-implementacion-la

5. Stiglitz, J.E.: The role of government in economic development. In: Annual World Bank Conference on Development Economics, pp. 11-23. World Bank, Washington D.C. (1997)

6. Urzúa, M.A., Caqueo-Urízar, A.: Calidad de vida: Una revisión teórica del concepto. Terapia psicológica 30(1), 61-71 (2012)

7. Pissourios, I.: An interdisciplinary study on indicators: a comparative review of quality-of-life, macroeconomic, environmental, welfare and sustainability indicators. Ecol. Ind. 34, 420-427 (2013). https://doi.org/10.1016/j.ecolind.2013.06.008

8. Juknys, R., Liobikienè, G., Dagiliūtè, R.: Deceleration of economic growth - the main course seeking sustainability in developed countries. J. Clean. Prod. 192(10), 1-8 (2018) 
9. Flavin, P.: State government public goods spending and citizens' quality of life. Soc. Sci. Res. 78, 28-40 (2019). https://www.sciencedirect.com/science/article/pii/S0049089X18302801

10. Wallace, M., Wu, Q.: Immigration and the quality of life in U.S. metropolitan areas. Soc. Sci. J. 56, 443-457 (2018). https://doi.org/10.1016/j.soscij.2018.09.016. https://www.scienc edirect.com/science/article/pii/S0362331918301411

11. Hu, S., Das, D.: Quality of life among older adults in China and India: does productive engagement help? Soc. Sci. Med. 229, 144-153 (2019). https://www.sciencedirect.com/sci ence/article/pii/S0277953618303368

12. CAF - Banco de Desarrollo de América Latina. Encuesta anual a individuos en hogares Trayectorias laborales y productivas en América Latina 2017. CAF, Caracas (2017). http:// scioteca.caf.com/handle/123456789/1400

13. Molina, E.: Imputación múltiple de ingresos individuales y familiares en la encuesta CAF 2017. Presentación, Métodos y Ejemplos. CAF, Caracas (2018)

14. Lis-Gutiérrez, J.P., Reyna-Niño, H.E., Gaitán-Angulo, M., Viloria, A., Abril, J.E.S.: Hierarchical ascending classification: an application to contraband apprehensions in Colombia (2015-2016). In: Tan, Y., Shi, Y., Tang, Q. (eds.) Data Mining and Big Data. Lecture Notes in Computer Science, vol. 10943, pp. 168-178. Springer, Cham (2018). https://doi.org/10. 1007/978-3-319-93803-5_16 